\title{
Deciphering the composition and structure of Wyoming craton mantle lithosphere: insights from peridotite xenoliths
}

\author{
Benjamin Parks ${ }^{1}$, Emily J. Chin ${ }^{2}$, Alberto Saal ${ }^{1}$, Greg Hirth ${ }^{1}$, Carter Hearn ${ }^{3}$, Jean- \\ Louis Bodinier ${ }^{4}$ \\ ${ }^{1}$ Brown University,Providence,USA, benjamin_parks@brown.edu,alberto_saal@brown.edu, \\ greg_hirth@brown.edu \\ ${ }^{2}$ Scripps Institution of Oceanography,La Jolla,USA,e8chin@ucsd.edu \\ ${ }^{3} U S G S$, Reston,USA, chearn@usgs.gov \\ ${ }^{4}$ Université de Montpellier, Montpellier, France
}

\section{Introduction}

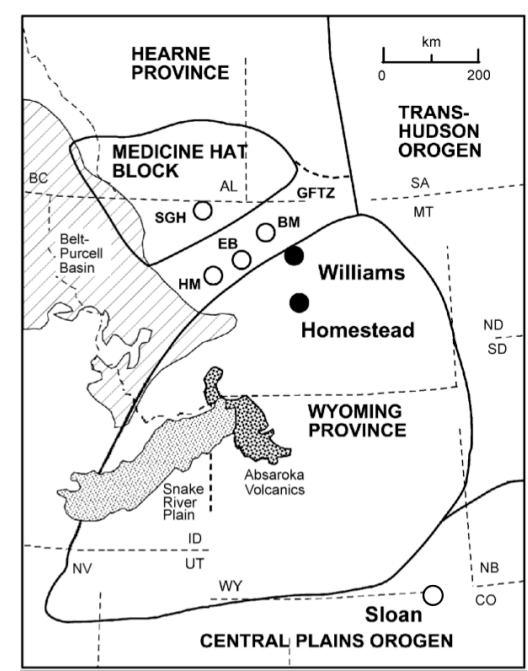

Figure 1: Tectonic map of the Homestead and Williams sample locations with respect to the Wyoming craton and other neighboring basement geologic terranes. Modified from Carlson et al. (2004).

The Wyoming craton stands out among Archean cratons as one that underwent widespread, thickskinned deformation relatively recently, specifically during the Laramide orogeny. If this deformation occurred within the lithospheric mantle of the Wyoming craton, the thermal, compositional, and rheological effects of this tectonism should be documented by the xenoliths subsequently transported to the surface. A large portion of the mantle xenolith-bearing magmatism occurred in the Eocene-aged Montana high-potassium igneous province at the end of the Laramide (Hearn Jr. 1989; O'Brien, et al. 1991). The xenoliths in this region span the northwestern margin of the Wyoming craton (Figure 1A). In particular, two kimberlite diatremes bear an abundance of garnet and garnet-spinel peridotites: the Homestead diatreme, located toward the the interior of the craton, and the Williams diatreme, located near the Proterozoic-aged Great Falls Tectonic Zone. To elucidate how Wyoming cratonic mantle has been modified prior to and during the Laramide, we present the first integrated investigation of mineral major and trace element compositions and deformation microstructures of peridotite xenoliths from the Homestead and Williams kimberlites.

\section{Xenolith Suites \& Petrography}

Garnet and garnet-spinel peridotite xenoliths sampled from the Homestead and Williams kimberlites can be divided into three groups. The Williams xenoliths comprise one low-temperature group (group LTW) and one high-temperature group (group HTW), as previously categorized (Carlson, et al. 1999). The third group consists of the Homestead xenoliths (group HS). Among all groups, the xenoliths are predominantly harzburgites, while less than $15 \%$ of the samples are lherzolites. 


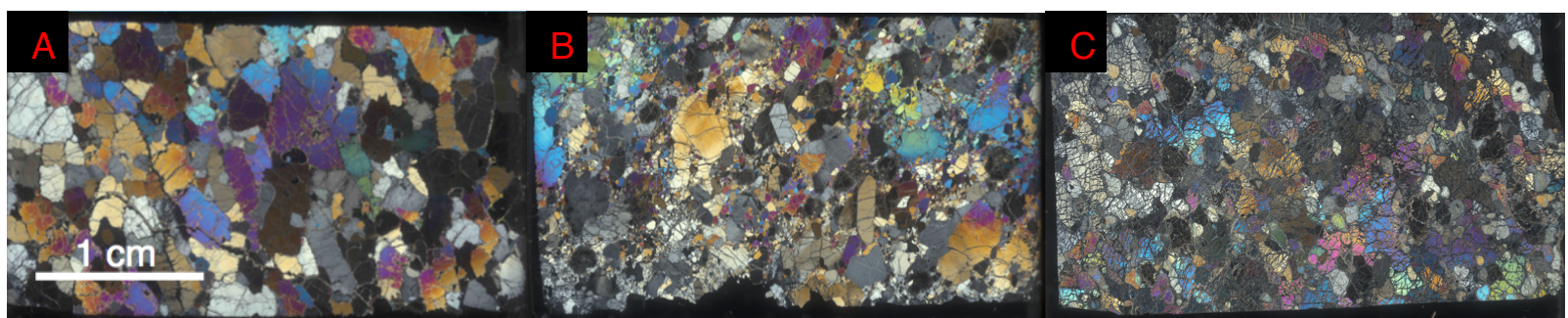

Figure 2: Photomicrographs in cross-polarized light of samples from each of the three xenolith groups: group LTW sample H68-16B (A), group HTW sample H81-26 (B), and group HS sample H00-11-16 (C).

LTW xenoliths yield inter-mineral major element equilibrium temperatures of $850-1050^{\circ} \mathrm{C}$ and $\sim 3-4.2$ $\mathrm{GPa}$, which fall along a $38 \mathrm{~mW} / \mathrm{m}^{2}$ shield geotherm (Hearn Jr. 2004). This group exhibits a coarse tabular texture with weak foliation relative to group HTW, and predominantly isolated garnet and clinopyroxene grains (Figure 2A). Group HTW is hotter than this shield geotherm, yielding temperatures of $1100-1450^{\circ} \mathrm{C}$ and pressures of $4-5.5 \mathrm{GPa}$, and exhibit coarse porphyroclastic to mosaic porphyroclastic textures (Figure 2B). Olivine grains in HTW samples appear as mm-scale porphyroclasts, smaller anhedral neoblasts, and in polygonal tablets that overprint porphyroblasts and neoblasts, which suggests the occurrence of post-deformation annealing. Group HS yields similar P-T estimates to group HTW, with temperatures of $1100-1400^{\circ} \mathrm{C}$ and pressures of 3.6-4.8 GPa (Hearn Jr. 2004). Group HS xenoliths exhibit predominantly coarse grained to coarse-porphyroclastic textures, including a subset of samples exhibiting coarse grained textures with intimately associated garnet and clinopyroxene (Figure 2C). Re-depletion model ages of group LTW (1.77-2.55 Ga, Carlson, et al. $1999)$ and group HS (2.30-2.77 Ga, Carlson, et al. 2004) are significantly older than the ages of group HTW $(<0.83 \mathrm{Ga}$, Carlson, et al. 1999). However, the highly variable and unreliable garnet and clinopyroxene tie-line ages given by Rb-Sr, Lu-Hf, and Sm-Nd isotopes for Williams and Homestead peridotite xenoliths (Carlson et al. 2004) suggest that significant, more recent melt-rock interaction occurred.

\section{Mineral Chemistry}

Mineral compositions of the sampled xenoliths are generally depleted with respect to major elements. Most olivine $\mathrm{Mg} \#$ values range from 0.91 to 0.93 , falling within the expected range for cratonic peridotites (Bernstein, et al. 2007). The exceptions are two HS samples (one of which is sample H0011-16, Figure 2C), both with olivine $\mathrm{Mg} \#=0.90$. In clinopyroxenes, molar $\mathrm{Cr} / \mathrm{Al}$ ratios correlate positively with $\mathrm{Mg \#}$; H00-11-16 clinopyroxenes yield the lowest $\mathrm{Cr} / \mathrm{Al}(<0.3)$, which indicates relatively low depletion, while grains from LTW sample $\mathrm{H} 68-16 \mathrm{~B}$ yield the highest $(\sim 0.6)$, indicating high depletion. Among all samples, $\mathrm{H} 68-16 \mathrm{~B}$ yields the largest range in garnet $\mathrm{Cr}_{2} \mathrm{O}_{3}$ concentrations, such that rims have lower range in $\mathrm{Cr}_{2} \mathrm{O}_{3}$ (4.0-5.7 wt.\%) than cores (4.2-6.4 wt.\%).
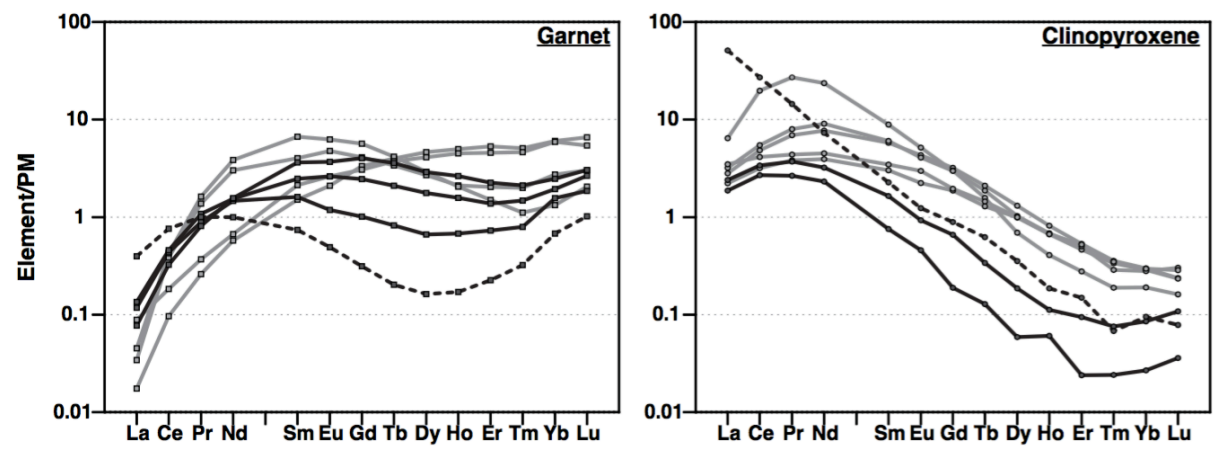

Figure 3: Primitive mantle- normalized REE concentrations in garnet (left) and clinopyroxene (right) for groups HS (solind grey lines), LTW (dashed black lines), and HTW (solid black lines). Normalizing concentrations from McDonough and Sun (1995). 
Trace element compositions of garnet and clinopyroxene show significant systematic variations in enrichment, indicating varying degrees and styles of metasomatism among the analyzed sample suite (Figure 3). Primitive-mantle normalized REE patterns in clinopyroxenes range from MREE-enriched (i.e., $\left.(\mathrm{La} / \mathrm{Nd})_{\mathrm{N}}<1\right)$ for groups HTW and HS to LREE-enriched (i.e., $(\mathrm{La} / \mathrm{Nd})_{\mathrm{N}}>1$ ) for group LTW. For most of the observed samples, garnets have sinusoidal REE patterns. The two HS samples with low olivine $\mathrm{Mg} \#$ and low cpx $\mathrm{Cr} / \mathrm{Al}$ have monotonic garnet REE patterns. The low level of depletion in the HS samples that have monotonic REE patterns suggests that parts of the Wyoming craton lithosphere beneath Homestead interacted with an infiltrating melt/fluid at a high melt/fluid-to-rock ratio, while the garnet, cpx and melt/fluid approach chemical equilibrium. In contrast, group LTW, represented by sample H68-16B, shows significant chemical disequilibrium, based on between- and within-grain variation in major element and REE concentrations.

\section{Crystallographic-preferred orientations}

The crystallographic-preferred orientations (CPO) of olivines, measured using EBSD, indicate that these peridotites record different fabrics. CPO patterns, shown in Figure 4 for LTW sample H68-16B and HS sample H00-11-16. In the HS sample, opx and olivine align in the [001] direction, parallel to lineation and parallel to the (100) plane, which indicates a B-type fabric. Though few were measured, opx CPOs in both samples appear aligned with olivine CPO perpendicular to foliation in the (010) plane. The significantly different CPO for H00-11-16 may signify that the deformation conditions reflected by mineral CPOs may relate to its relatively undepleted, well-equilibrated chemical composition. Such traits suggest that prior to the ascent of these xenoliths to the surface, considerable removal and (or) reworking of the base of the Wyoming craton mantle lithosphere occurred, potentially related to the Laramide orogeny.

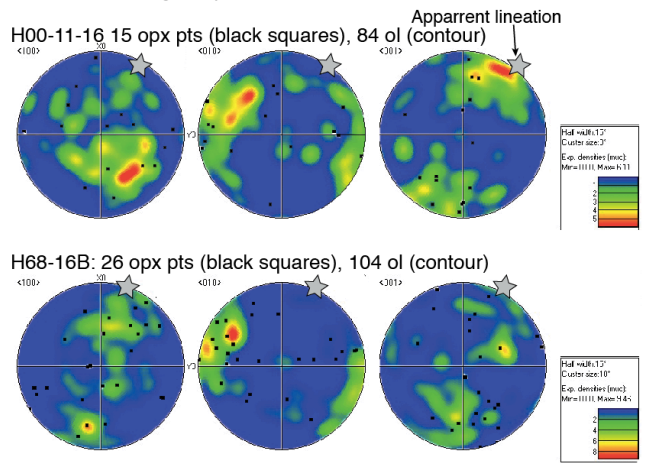

Figure 4: Olivine and orthopyroxene CPO patterns, plotted as lower hemisphere, equal-area projections.

\section{References}

Bernstein S, Kelemen PB, Hanghøj K (2007) Consistent olivine Mg\# in cratonic mantle reflects Archean mantle melting to the exhaustion of orthopyroxene. Geology 35(5):459-462

Carlson R, Irving A, Hearn Jr. B (1999) Chemical and isotopic systematics of peridotite xenoliths from the Williams kimberlite, Montana: clues to processes of lithosphere formation, modification and destruction. In: Proceedings of the VIIth International Kimberlite Conference, vol 1. pp 90-98

Carlson RW, Irving AJ, Schulze DJ, Hearn Jr. BC (2004) Timing of Precambrian melt depletion and Phanerozoic refertilization events in the lithospheric mantle of the Wyoming Craton and adjacent Central Plains Orogen. Lithos 77(1):453-472

Hearn Jr. BC (1989) Introduction: T346 Montana High-Potassium Igneous Province. Montana HighPotassimn Igneous Province: Crazy Mountains to Jordan, Montana:1-5

Hearn Jr. BC (2004) The Homestead kimberlite, central Montana, USA: mineralogy, xenocrysts, and upper-mantle xenoliths. Lithos 77(1):473-491

McDonough WF, Sun SS (1995) The composition of the Earth. Chemical geology 120(3):223-253

O'Brien HE, Irving AJ, McCallum IS (1991) Eocene potassic magmatism in the Highwood Mountains, Montana: petrology, geochemistry, and tectonic implications. Journal of Geophysical Research: Solid Earth 96(B8):13237-13260 